\title{
OCENA TŁOCZNOŚCI BLACH METODAMI ENGELHARDTA I ERICHSENA
}

\begin{abstract}
Badania tłoczności blach są ciągle przedmiotem zainteresowania przemysłu, aby zapewnić bezproblemową produkcję i dobrą jakość wyrobów. W artykule przedstawiono ocenę tłoczności wybranych materiałów za pomocą metod Erichsena i Engelhardta. Wyniki doświadczalne przedstawiono dla czterech różnych gatunków blach używanych w przemyśle: stalowej DC01, miedzianej Cu-ETP, mosiężnej CuZn37 i z aluminium EN-AW1050A. Właściwości mechaniczne tych materiałów zostały określone w statycznej próbie rozciągania. Próbę Erichsena wykorzystano do określenia głębokości wtłoczenia stempla w materiał w momencie jego pęknięcia, zdefiniowanej jako IE Erichsena. Badania eksperymentalne mające na celu określenie rezerwy tłoczności w próbie Engelhardta przeprowadzono na maszynie wytrzymałościowej ZD100 (1. klasa metrologiczna w zakresie pomiaru sił i przemieszczeń), wyposażonej w specjalny tłocznik. Rezultaty uzyskane w pracy mogą zostać wykorzystane jako wytyczne do projektowania ciągnienia wytłoczek o różnych kształtach $\mathrm{z}$ blach stalowych i metali nieżelaznych w praktyce produkcyjnej.
\end{abstract}

Słowa kluczowe: obróbka plastyczna, właściwości mechaniczne, tłoczność blach

\section{Wprowadzenie}

Tłoczność jest zwykle definiowana w literaturze przedmiotu jako podatność blach na tłoczenie (ciągnienie) [1], zdolność materiału do odkształceń plastycznych w procesie tłoczenia [2] lub przydatność metali do odkształceń plastycznych [3]. Ocenę tłoczności blach powinno się określać kompleksowo na podstawie wyników badań właściwości mechanicznych materiału, struktury i wielkości ziaren, dodatkowych obserwacji (np. stwierdzających obecność pasm poślizgów na powierzchni rozciąganej próbki, kształtu pęknięcia), wyników prób technologicznych [1] oraz innych (np. wyznaczonych wskaźników anizotropii normalnej i płaskiej blachy, wartości względnego wydłużenia równomiernego, rzeczywistego naprężenia rozciągającego [3] oraz wykładnika krzywej umocnienia, odkształcenia wstępnego, stopnia jednorodności blachy [2]). Ze względu na złożoność wymienionych badań, wymagających dysponowania odpowiednią aparaturą i zapleczem, w praktyce przemysłowej do określenia tłoczności zwykle stosuje

${ }^{1}$ Autor do korespondencji/corresponding author: Tomasz Miłek, Politechnika Świętokrzyska, 25-314 Kielce, al. Tysiąclecia Państwa Polskiego 7, tel.: (41)3424373, e-mail: tmatm@tu.kielce.pl 
się wybrane badania właściwości mechanicznych oraz próby technologiczne. $\mathrm{Z}$ uwagi na specyfikę różnych sposobów tłoczenia materiału (np. ciągnienie wytłoczek o różnych kształtach i gięcie materiału), wynikającą m.in. z różnego stanu naprężenia w tych procesach, brakuje uniwersalnej metody oceny tłoczności blach. Próby technologiczne mające na celu określenie przydatności materiału do odkształceń plastycznych powinny być zbliżone do warunków, w jakich znajduje się materiał w czasie obróbki tłoczeniem $[1,3]$. Są one ciągle przedmiotem zainteresowania przemysłu, w celu zapewnienia bezproblemowej produkcji i dobrej jakości wyrobów [4].

W artykule skoncentrowano się na najczęściej stosowanych próbach Engelhardta i Erichsena. Pierwsza uwzględnia stan naprężenia materiału panujący podczas ciągnienia wytłoczek cylindrycznych, druga zaś podczas ciągnienia wytłoczek sferycznych. Próba Engelhardta (w literaturze określana również jako próba według idei Engelhardta i Grossa [1]) polega na dwuetapowym wytłoczeniu cylindrycznej wytłoczki o odpowiednich wymiarach. W pierwszym etapie wytłoczka musi mieć wysokość większą od wysokości, przy której występuje maksymalna siła $\mathrm{F}_{\mathrm{m}}$. Po niewielkim spadku siły tłoczącej należy próbę przerwać i mocno docisnąć kołnierz tworzącej się miseczki za pomocą dociskacza kształtowego. W drugim etapie dalsze odkształcenie materiału następuje kosztem rozciągania części cylindrycznej wytłoczki do momentu pęknięcia jej w okolicy dna przy sile niszczącej $F_{z r}$. Kryterium tłoczności w tej próbie przedstawia stosunek (1), który charakteryzuje rezerwę zdolności tłocznej materiału w warunkach, w których została ona zrealizowana [1]:

$$
\mathrm{T}=\frac{\mathrm{F}_{\mathrm{zr}}-\mathrm{F}_{\mathrm{m}}}{\mathrm{F}_{\mathrm{zr}}} 100 \%
$$

gdzie: $F_{z r}$ - siła zrywająca, $F_{m}$ - siła maksymalna.

Wskaźnik ten teoretycznie nie zależy od grubości blachy (Engelhrdt w swoich badaniach dla stali i metali nieżelaznych wykazał, że dla blach z tego samego materiału, lecz o różnej grubości wskaźnik T zmienia się bardzo nieznacznie [1]). Swoje rozważania oparł na podanych dalej wzorach. Wyprowadził wzór na siłę tłoczenia:

$$
\mathrm{F}_{\mathrm{m}}=\mathrm{d} \cdot \pi \cdot \mathrm{g} \cdot \sigma_{\mathrm{plsr}} \ln \frac{\mathrm{D}}{\mathrm{d}} \cdot \frac{1}{\eta}
$$

oraz wzór na siłę zrywającą [1]:

$$
\mathrm{F}_{\mathrm{zr}}=\mathrm{d} \cdot \pi \cdot \mathrm{g} \cdot \mathrm{R}_{\mathrm{m}} \cdot x
$$


Engelhardt podał również warunek wytrzymałościowy w przekroju niebezpiecznym [1]:

$$
\sigma_{\mathrm{plsr}} \ln \frac{\mathrm{D}}{\mathrm{d}} \leq \mathrm{R}_{\mathrm{m}} \cdot \mathrm{x}
$$

gdzie: $\sigma_{\mathrm{pl} \mathrm{sr}}$ - średnia granica plastyczności z $\sigma_{\mathrm{pl}}$ na brzegu kołnierza oraz na krawędzi matrycy,

$\mathrm{R}_{\mathrm{m}}$ - wytrzymałość materiału na rozciąganie,

$\ln \frac{D}{d}=\delta$ - rzeczywiste odkształcenie w rozpatrywanej chwili ciągnienia,

$\eta=0,5-0,6-$ współczynnik sprawności procesu,

$\mathrm{x}=1,0-1,1-$ współczynnik wpływający na zmianę wytrzymałości $\mathrm{R}_{\mathrm{m}}$, zależny od stanu naprężenia.

Na podstawie wzorów (1)-(3) wyprowadził on i przedstawił wzór (5) na teoretyczny wskaźnik tłoczności w jego próbie [1]:

$$
\mathrm{T}=\left(1-\frac{\sigma_{\mathrm{plss}} \cdot \ln \frac{\mathrm{D}}{\mathrm{d}}}{\mathrm{R}_{\mathrm{m}} \cdot \mathrm{x} \cdot \eta}\right) \cdot 100 \%
$$

Erichsen swoją próbę technologiczną oceny tłoczności opatentował w 1913 r. [5]. Jako jedna z niewielu jest metodą znormalizowaną [6], wykonywaną na specjalnych przyrządach. Wielkością charakteryzującą podatność blachy do ciągnienia w tej próbie jest głębokość wtłoczenia kulki lub sferycznego stempla w próbkę dociśniętą do matrycy za pomocą dociskacza płaskiego, do momentu powstania w niej pęknięcia. Jest określana liczbą Erichsena IE $[1,5,6]$. Jednocześnie obserwuje się kształt pęknięcia oraz powierzchnię materiału na wierzchołku kulistej czaszy [1]. W ostatnim czasie pojawiło się wiele prac dotyczących badań materiałowych, opartych m.in. na próbie Erichsena [7-11]. Kocańda i Jasiński [7] zaproponowali wprowadzenie dodatkowego parametru w próbie Erichsena, tj. wysokości czaszy (oznaczanej jako LN-IE) w momencie zlokalizowania pocienienia blachy poprzedzającego pęknięcie materiału. W tym celu opracowali własną metodę wykorzystującą zjawisko widma laserowego pojawiającego się na chropowatej powierzchni oświetlonej plamką lasera. W badaniach doświadczalnych dla blach ze stopu aluminium 5754H22 oraz stalowych DC04 i Dogal800DP wykazali niewielkie różnice (0-8\%) między ich wskaźnikiem LN-IE a standardowym wskaźnikiem Erichsena IE [7]. Sigh i inni [8] przeprowadzili analizę tłoczności blach o różnej grubości ze stopu aluminium AA 1200. Porównali wyniki wskaźników Erichsena IE uzyskane w różnych warunkach, tj. dla próbek bez 
smaru i smarowanych olejem hydraulicznym do pras oraz nagrzewanych w temperaturach z zakresu od 50 do $200^{\circ} \mathrm{C}$. Toit i Steyn [9] przeprowadzili ocenę porównawczą tłoczności blach z austenitycznych stali nierdzewnych AISI 202 i AISI 304 o grubości $0,7 \mathrm{~mm}$. W pracy [9] porównali wyniki twardości Vickersa wybranych właściwości z próby rozciągania, obliczone wskaźniki określające anizotropię normalną i płaską blachy (odpowiednio wskaźnik Lankforda i wskaźnik różnicowy Kellera) oraz wskaźniki z próby Erichsena dla badanych materiałów. Tamimi i inni [10] połączyli badania doświadczalne tłoczności blachy ze stopu aluminium AA 5083 (PA13) o grubości 1,2 mm metodą Erichsena z modelowaniem komputerowym procesu w programie DEFORM (opartym na MES).

Celem badań przedstawionych $\mathrm{w}$ artykule była ocena tłoczności różnych gatunków blach, opierająca się na statycznej próbie rozciągania metali oraz wybranych metodach badania tłoczności Erichsena i Engelhardta, uwzględniająca odpowiednio stan naprężenia materiału panujący podczas ciągnienia wytłoczek cylindrycznych oraz sferycznych.

\section{Metodyka badań}

Badania doświadczalne przeprowadzono dla różnych gatunków blach: stalowej DC01, miedzianej Cu-ETP, z mosiądzu CuZn37 oraz aluminium EN-AW1050A, o grubości nominalnej $\mathrm{g}_{0}=1 \mathrm{~mm}$. Wyznaczono właściwości mechaniczne na podstawie statycznej próby rozciągania, zgodnie z wymaganiami [11]. Ich uśrednione wartości przedstawiono w tab. 1., a uzyskane wykresy siły w funkcji przemieszczenia - na rys. 1. Do badań tłoczności metodą Engelhardta zostały przygotowane próbki w postaci krążków o średnicy $\mathrm{D}=73,5 \mathrm{~mm}$, natomiast do próby Erichsena blachy rozcięto na pasy o szerokości $b=90 \mathrm{~mm}$. Próbę rozciągania przeprowadzono na maszynie wytrzymałościowej LabTest5.20SP1 (firmy LaborTech), spełniającej wymagania metrologiczne dla klasy 0,5 w zakresie pomiarowym od 0,2 do $20 \mathrm{kN}$ dla wartości względnych błędów układu pomiaru siły oraz względnej rozdzielczości wskaźnika siły. Maszynę wyposażono w komputerowe stanowisko z oprogramowaniem Test \& Motion firmy LaborTech do pomiaru sił i przemieszczeń.

Tabela 1. Właściwości mechaniczne próbek użytych w badaniach

Table 1. Mechanical properties of specimens

\begin{tabular}{|l|l|l|l|l|}
\hline \multicolumn{1}{|c|}{ Materiał } & $\mathrm{R}_{\mathrm{m}}[\mathrm{MPa}]$ & $\mathrm{R}_{0,2}[\mathrm{MPa}]$ & $\mathrm{A}_{5}[\%]$ & $\mathrm{A}_{10}[\%]$ \\
\hline $\mathrm{Cu}-\mathrm{ETP}$ & 249 & 239 & 64 & 56 \\
\hline CuZn37 & 371 & 289 & 53 & 45 \\
\hline DC01 & 317 & 189 & 65 & 53 \\
\hline EN-AW1050A & 120 & 111 & 16 & 9 \\
\hline
\end{tabular}




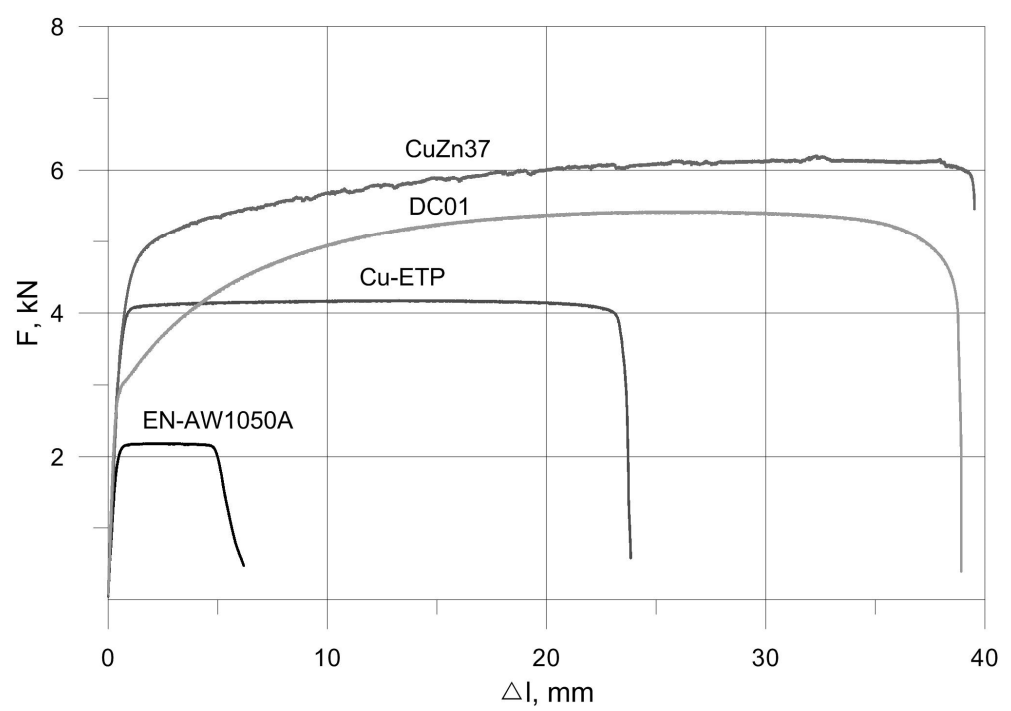

Rys. 1. Wykresy rozciągania próbek z różnych gatunków materiałów

Fig. 1. Characteristics of uniaxial stretching of samples from various types of materials

Próbę tłoczności metodą Engelhardta przeprowadzono na tłoczniku, zamontowanym na maszynie wytrzymałościowej ZD100, zmodyfikowanej przez firmę Labortech (Czechy), o nacisku $1 \mathrm{MN}$, spełniającej wymagania metrologiczne dla klasy 1. zgodnie z PN-EN ISO 7500-1:2005. Maszyna jest wyposażona w komputerowe stanowisko z oprogramowaniem Test\&Motion firmy LaborTech do pomiaru sił i przemieszczeń. Schemat użytego tłocznika do badania tłoczności metodą Engelhardta przedstawiono na rys. 2. Średnice wynosiły odpowiednio

Rys. 2. Tłocznik do wyznaczania tłoczności blach metodą Engelhardta; 1 - matryca, 2 - stempel, 3 - dociskacz płaski, 4 - dociskacz kształtowy, 5, 6 - śruby dociskowe, 7 - obsada, 8 - wytłoczka

Fig. 2. Laboratory press-forming die for determination of formability by Engelhardt method; 1 - die, 2 - punch, 3 - flange holder, 4 - shape holder, 5, 6 - set screws, 7 - die holder, 8 - drawpiece

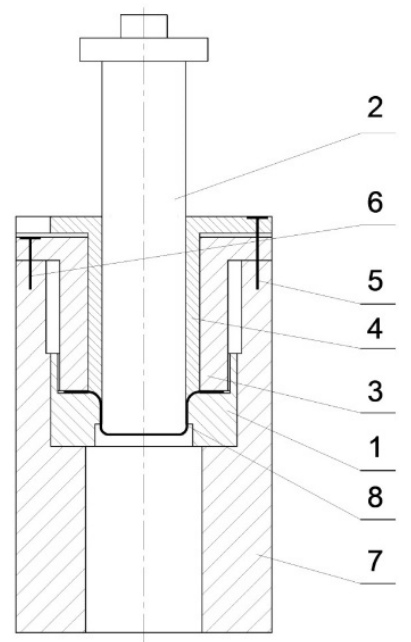


stempla $\mathrm{d}_{\mathrm{s}}=36 \mathrm{~mm}$, matrycy $\mathrm{d}_{\mathrm{m}}=38 \mathrm{~mm}$. Próbę tłoczności metodą Erichsena przeprowadzono na specjalnym przyrządzie. Schemat użytych narzędzi kształtujących wraz $\mathrm{z}$ wymiarami przedstawiono na rys. 3. Wymiary zastosowanego stempla, matrycy i dociskacza były zgodne z literaturowymi zaleceniami [6].

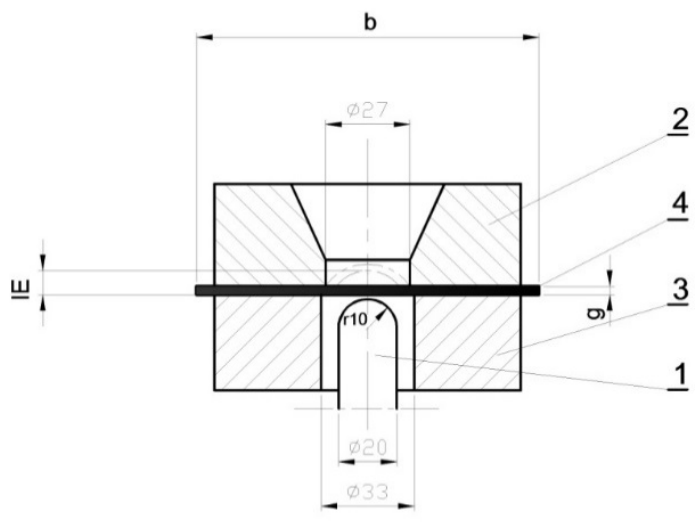

Rys. 3. Schemat badania tłoczności metodą Erichsena; 1 - stempel, 2 - matryca, 3 - dociskacz, 4 - próbka

Fig. 3. Scheme of Erichsen cup ping test; 1 - punch, 2 - die, 3 - blankholder, 4 - sample

\section{Wyniki badań}

Badania z zakresu próby tłoczności Engelhardta i Erichsena przeprowadzono zgodnie z literaturowymi zaleceniami [1,6]. Przykładowe próbki z mosiądzu przedstawiono na rys. 4.



b)

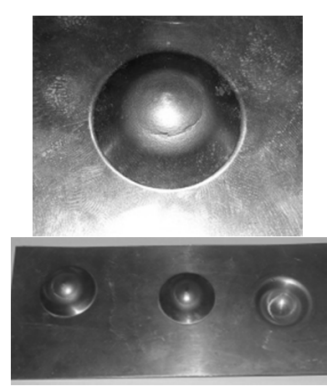

Rys. 4. Przykłady próbek z mosiądzu CuZn37 uzyskane w próbach tłoczności: a) Engelhardta, b) Erichsena

Fig. 4. Examples of samples made of $\mathrm{CuZn} 37$ brass obtained in formability tests: a) Engelhardt, b) Erichsen

Próbę Engelhardta przeprowadzono dwuetapowo na tłoczniku (rys. 2.). Próbki smarowano smarem na bazie głęboko rafinowanego oleju mineralnego zagęszczonego mydłami litowymi, o właściwościach wysokotemperaturowych 
i umieszczano w matrycy, po czym dociskano je dociskaczem płaskim, aby nie dopuścić do fałdowania kołnierza (ponieważ g < 0,02D [3, 12]). W pierwszym etapie wytłaczano wytłoczkę do momentu osiągnięcia siły $F_{m} i$ jej nieznacznego spadku. Następnie przerywano proces wytłaczania i dociskano kołnierz wytłoczki dociskaczem kształtowym, na promieniu przejścia wytłoczki z części walcowej w kołnierz. W drugim etapie kontynuowano proces ciągnienia, w którym odkształcenie materiału następowało kosztem rozciągania części cylindrycznej wytłoczki, do momentu jej pęknięcia w okolicy dna przy sile $F_{z r}$. Uzyskano pomyślne wyniki prób dla próbek stalowych DC01, miedzianych Cu-ETP oraz mosiężnych CuZn37. W przypadku próbek z aluminium EN-AW1050A za każdym razem dochodziło do ich pękania w pierwszym etapie próby, co uniemożliwiało rejestrację siły $\mathrm{F}_{\mathrm{zr}} \mathrm{w}$ drugiej fazie. Dla każdej próbki rejestrowano wykresy z obu etapów pomyślnie przeprowadzonych prób. Kompletne wykresy z próby Engelhardta dla próbek z DC01, Cu-ETP i CuZn37 przedstawione na rys. 5. były więc ich złożeniem.

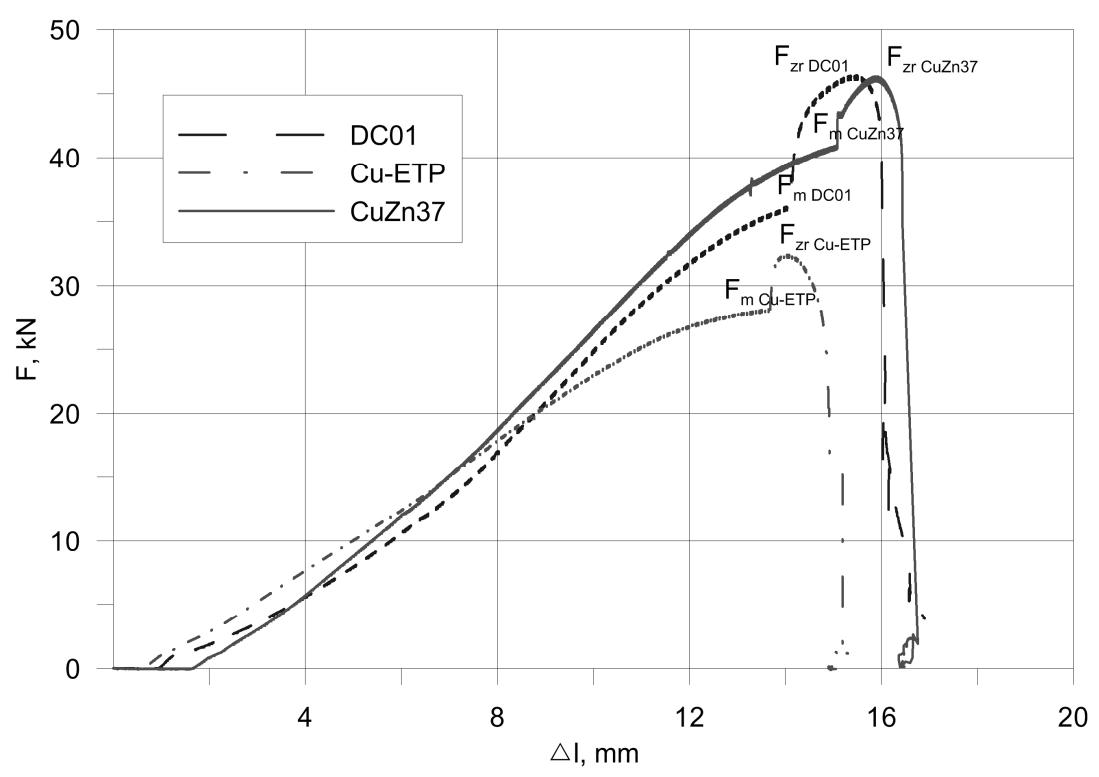

Rys. 5. Zależność siły od przemieszczenia stempla w próbie Engelhardta dla blach CuZn37, Cu-ETP oraz stali DC01

Fig. 5. The dependence of force on the stamp movement in the Engelhardt test for CuZn37, Cu-ETP and DC01 steel sheets

Opierając się na wartości sił $\mathrm{F}_{\mathrm{m}}$ i $\mathrm{F}_{\mathrm{zr}}$, które zostały uśrednione $\mathrm{z}$ pięciu pomiarów, dla każdego gatunku materiału obliczono wskaźniki T z próby Engelhardta ze wzoru (1). Wskaźniki T obliczano również ze wzoru (5), korzystając $\mathrm{z}$ właściwości materiału wyznaczonych $\mathrm{w}$ statycznej próbie rozciągania, poda- 
nych w tab. 1. W przypadku próbek stalowych DC01 i miedzi Cu-ETP wskaźniki T obliczone ze wzoru (5) były większe odpowiednio o 26 i 19\% od wskaźników obliczonych ze wzoru (1). Tylko w przypadku próbki z mosiądzu CuZn37 tendencja była odwrotna i wskaźnik T obliczony ze wzoru (5) był mniejszy od wskaźnika T obliczonego ze wzoru (1) o 38\%. W tabeli 2. przedstawiono uzyskane wyniki obliczeń wskaźników $\mathrm{T}$ z próby Engelhardta wraz $\mathrm{z}$ uśrednionymi wynikami wskaźnika IE z pięciu pomiarów dla każdego rodzaju materiału z próby Erichsena.

Tabela 2. Wskaźniki tłoczności w próbach Engelhardta i Erichsena

Table 2. Formability indicators in Engelhardt and Erichsen's tests

\begin{tabular}{|l|c|c|c|c|}
\hline \multicolumn{1}{|c|}{ Materiał } & $\begin{array}{c}\mathrm{g}_{0} \\
{[\mathrm{~mm}]}\end{array}$ & $\begin{array}{c}\mathrm{T}[\%] \\
\text { ze wzoru (1) }\end{array}$ & $\begin{array}{c}\mathrm{T}[\%] \\
\text { ze wzoru (5) }\end{array}$ & $\begin{array}{c}\mathrm{IE} \\
{[\mathrm{mm}]}\end{array}$ \\
\hline DC01 & 0,99 & 22,46 & 28,24 & 12,30 \\
\hline Cu-ETP & 0,99 & 13,06 & 15,50 & 9,55 \\
\hline CuZn37 & 0,99 & 10,02 & 6,24 & 9,17 \\
\hline EN-AW1050A & 1,02 & - & 1,52 & 8,11 \\
\hline
\end{tabular}

W ramach weryfikacji uzyskanych wyników, głównie z próby Engelhardta, przeprowadzono ciągnienie wytłoczek cylindrycznych bez kołnierza z badanych materiałów w czterech operacjach (wytłaczanie oraz trzy przetłaczania bez wyżarzania międzyoperacyjnego) na laboratoryjnym uniwersalnym tłoczniku z wymiennymi kompletami stempli i matryc, zamontowanym na prasie ZD100. Wymiary robocze zastosowanych matryc stempli podano w pracy [13]. Materiałem wyjściowym były krążki o średnicach $\mathrm{D}=66 \mathrm{~mm}$ (co odpowiadało względnemu stosunkowi $\left.\frac{\mathrm{g}_{0}}{\mathrm{D}} \cdot 100=1,5\right)$. Przyjęte współczynniki wytłaczania oraz przetłaczania wynosiły odpowiednio: $\mathrm{m}_{1}=0,55 ; \mathrm{m}_{2}=0,76 ; \mathrm{m}_{3}=0,82 ; \mathrm{m}_{4}=0,82$. Były one średnio o 5-10\% większe od minimalnych dopuszczalnych tablicowych współczynników dla stalowych wytłoczek cylindrycznych bez kołnierza, sugerowanych w literaturze przedmiotu i badaniach $[12,13]$. W trakcie wytłaczania zawsze stosowano dociskacz w celu uniknięcia fałdowania, ponieważ $\mathrm{g}<0,02 \mathrm{D}$. Nie stosowano dociskacza $w$ operacjach przetłaczania, ponieważ $\mathrm{g}>0,015 \mathrm{~d}_{\mathrm{n}-1}\left(\right.$ gdzie $_{\mathrm{n}-1}$ oznacza średnice wytłoczek przyjmowane według warstwy środkowej przed przetłaczaniem). Dla wszystkich badanych materiałów uzyskano pozytywne rezultaty, z wyjątkiem wytłoczek aluminiowych, które w około 30\% przypadków ulegały pękaniu (odrywaniu denka) w drugiej operacji (czyli przy pierwszym przetłaczaniu). Maksymalne smukłości wytłoczek w ostatniej operacji (czyli stosunek h/d) zawierały się w przedziale od 2,95 do 3,12, przy czym najniższe wartości uzyskiwano dla wytłoczek z aluminium (EN-AW1050A), a największe dla wytłoczek stalowych (DC01). Badania z zakresu wielooperacyjnego ciągnienia wytłoczek cylindrycznych bez kołnierza potwierdziły niską rezerwę tłoczności blachy z czystego aluminium uzyskaną w próbie Engelhardta, a także względnie niskie war- 
tości wytrzymałości na rozciąganie $\mathrm{R}_{\mathrm{m}}$ oraz umownej granicy plastyczności $\mathrm{R}_{0,2}$ dla tego materiału w statycznej próbie rozciągania (względnie niska jest również różnica między $\mathrm{R}_{\mathrm{m}}$ a $\mathrm{R}_{0,2}$, która wynosi tylko $8 \%$ ).

\section{Podsumowanie}

Na podstawie przeprowadzonych badań oceny tłoczności blach w próbach Engelhardta i Erichsena oraz statycznych próbach rozciągania dla różnych rodzajów materiałów: DC01, Cu-ETP, CuZn37 i EN-AW1050A o grubości nominalnej $\mathrm{g}_{0}=1 \mathrm{~mm}$ stwierdzono, że:

1. W każdej technologicznej próbie maksymalną rezerwę tłoczności posiadały próbki stalowe DC01, co potwierdziło największą przydatność tego materiału spośród pozostałych badanych do kształtowania wytłoczek o kształcie walcowym i sferycznym.

2. W próbie Erichsena najniższą rezerwę tłoczności miały próbki z aluminium, natomiast wskaźnik IE dla próbek z miedzi i mosiądzu był porównywalny. Wynik z próby Erichsena dla blachy stalowej DC01 potwierdził kategorię tłoczności, którą ten materiał posiada (blacha głębokotłoczna wg [14] ma minimalną dopuszczalną wartość wskaźnika IE dla $\mathrm{g}_{0}=1 \mathrm{~mm}$, wynoszącą $10,5 \mathrm{~mm}$ ).

3. Do szacunkowych inżynierskich obliczeń wskaźnika $\mathrm{T}$ z próby Engelhardta można wykorzystać wzór (5), gdy brak jest możliwości wyznaczenia sił $\mathrm{F}_{\mathrm{m}}$ i $\mathrm{F}_{\mathrm{zr}}$. Różnica w obliczonych wskaźnikach ze wzorów (1) i (5) nie przekracza 20-40\%. Trudnością w korzystaniu ze wzoru (5) może być dobór właściwego współczynnika sprawności procesu oraz współczynnika wpływającego na zmianę wytrzymałości, zależnego od stanu naprężenia materiału z powodu braku jednoznacznych i precyzyjnych literaturowych zaleceń w tym zakresie.

4. Wyniki uzyskane w badaniach mogą być pomocne do projektowania ciągnienia wytłoczek walcowych i sferycznych w warunkach produkcyjnych, zwłaszcza z blach aluminiowych, miedzianych i mosiężnych, $\mathrm{z}$ powodu skąpych informacji na ten temat $\mathrm{w}$ literaturze przedmiotu w odróżnieniu od opracowanych szczegółowych wytycznych dla blach stalowych.

\section{Literatura}

[1] Morawiecki M., Sadok L., Wosiek E.: Teoretyczne podstawy technologicznych procesów przeróbki plastycznej, Wydawnictwo „Śląsk”, Katowice 1977.

[2] Marciniak Z.: Odkształcenia graniczne przy tłoczeniu blach, WNT, Warszawa 1971.

[3] Romanowski W.P.: Poradnik obróbki plastycznej na zimno, WNT, Warszawa 1976.

[4] Hattalli V.L., Srivatsa S.R.: Sheet metal forming processes - recent technological advances, Materials today: Procedings, 5 (2018) 2564-2574. 
[5] Erichsen A.M.: Process and apparatus for testing metal sheets and plates, GB Patent no. 91228571 (A), 1913.

[6] Metale - Blachy i taśmy - Próba tłoczności metodą Erichsena. PN-EN ISO 20482.

[7] Kocańda A., Jasiński C.: Extended evaluation of Erichsen cupping test results by means of laser speckle, Arch. Civil Mech. Eng., 16 (2016) 211-216.

[8] Singh M., Choubey A.K. i in.: Formability analysis of aluminium alloy by Erichsen cupping test method, Materials Today: Proceedings, 4 (2017) 805-810.

[9] Toit M., Steyn H.G.: Comparing the formability of AISI 304 and AISI 202 stainless steel, J. Mater. Eng. Performance, 21 (2012) 1491-1495.

[10] Tamimi S., Sivaswamy G. i in.: Modelling and experimentation of the evolution of texture In an Al-Mg alloy during earing cupping test, Procedia Eng., 207 (2017) 1-6.

[11] Metallic materials - Tensile testing. Part 1: Method of test at room temperature. ISO 6892-1:2009 (E).

[12] Golatowski T.: Projektowanie procesów tłoczenia i tłoczników. Wybrane zagadnienia, Wydawnictwa Politechniki Warszawskiej, Warszawa 1984.

[13] Chałupczak J., Miłek T.: Wpływ stopnia zgniotu na wybrane parametry tłoczenia, Obróbka Plastyczna, 3 (1999) 5-10.

[14] PN-EN 10130:2009. Wyroby płaskie walcowane na zimno ze stali niskowęglowych do obróbki plastycznej na zimno - Warunki techniczne dostawy.

\title{
DETERMINATION OF FORMABILITY OF SHEET METAL BY ERICHSEN AND ENGELHARDT TESTS
}

\begin{abstract}
Sheet metal formability tests have been for a long time of interest to industry, as they ensure effortless manufacturing and good quality of products. The paper presents evaluation of the formability of sheet metal by Erichsen cupping test and Engelhardt method. The experimental results were presented for four different grades of sheet metal used in industry: DC01 deep drawing steel, $\mathrm{Cu}$-ETP copper, $\mathrm{CuZn} 37$ brass and EN-AW1050A aluminum. The mechanical properties of these materials were determined by static tensile testing. Erichsen cupping test was used to determine the height of the cup at the moment of sheet metal fracture, defined as the Erichsen IE Number. The experimental tests aimed to determine Engelhardt indikator were conducted on the ZD100 testing machine with special tooling. The results of investigations into formability tests might be used as guidelines to develop a technological deep drawing process for industrial practice.
\end{abstract}

Keywords: metal forming, mechanical properties, sheet metal formability

DOI: $10.7862 / \mathrm{rm} .2018 .16$

Przestano do redakcji: 16.05 .2018

Przyjęto do druku: 29.05.2018 